\title{
点滅する視覚障害者誘導用発光ブロックの視認性の検証
}

\section{Verification of Visibility of Blinking of LED Block for Guiding the Visually Impaired}

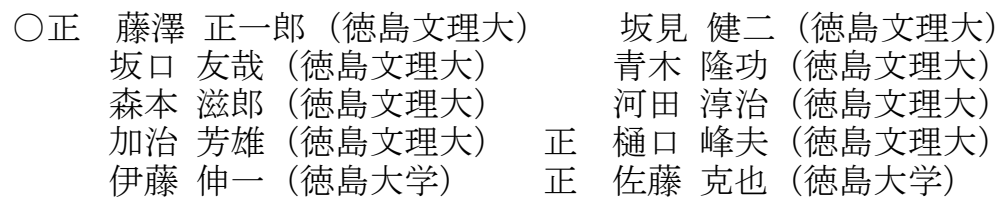

\author{
Shoichiro FUJISAWA, Tokushima Bunri University, s-fujisawa@fst.bunri-u.ac.jp \\ Kenji SAKAMI, Tokushima Bunri University \\ Tomoya SAKAGUCHI, Tokushima Bunri University \\ Takanori AOKI, Tokushima Bunri University \\ Jiro MORIMOTO, Tokushima Bunri University \\ Jyunji KAWATA, Tokushima Bunri University \\ Yoshio KAJI, Tokushima Bunri University \\ Mineo HIGUCHI, Tokushima Bunri University \\ Shin-ichi ITO, Tokushima University \\ Katsuya SATO, Tokushima University
}

\begin{abstract}
Vision is said to account for $80 \%$ of the information acquired of the five human senses. The presentation of light is an effective way to convey visual information. A blinking presentation especially attracts attention. A low-vision person acquires peripheral information through residual vision. In this case, light effectively supports the travel of low-vision persons. A blinking light stimulates more than a continuous light. However, a blinking light is not sufficiently compatible with the surrounding environment. This research investigates an environmentally friendly blinking pattern to arouse attention.
\end{abstract}

Key Words: Person with visually impairment, Low vision, LED block, Visibility, Sensory

\section{1. 緒言}

横断歩道の入り口は道路との境界に位置し，視覚障害者 1 人当たりの最も危険な場所の 1 つである，視覚障害者には， 盲人および弱視者 (LV) が含まれる. 光の提示は，視覚障害 者の約 $80 \%$ を占める LV 人のための効果的な援助である. 視覚 障害者の移動支援の研究は多数ある $[1]-[4]$. 著者らは横断歩 道口で横断を支援する LED ブロックを開発した [5], [6]。弱視 者は残存視野を用いて開発した LED ブロックを検出すること ができる. LED ブロックは太陽光を利用し, 常にオンになって います. しかし, 自動車のヘッドライトや周辺光のために, 道路環境においてそのような光の LED ブロックを見つけるこ とは困難である。このような状況では，光を点滅させること によって発見を容易にすることが可能である. しかし, 点滅 する発光の刺激が強すぎる可能性がある。一般に, 感覚の刺 激と脳波との間に相関がある。しかし, 我々は, 感覚の刺激 が低く, 脳の刺激が高い点滅パターンを提案した。提案され たルミネセンスパターンは，オン - オフを点滅させるのでは なく, むしろ円滑にオンおよびオフを切り替える.この発光 パターンは，消費電力を低減することができ，周辺住民を妨 害せず, 弱視者の移動支援に安心している. 本論文では, 様々 な点滅発光パターンによる刺激の違いを検証し, 有効な発光 パターンを提案する.

\section{2. 実験方法}

\section{1 点灯パターン}

今回の実験では 12 パターンの点滅を用意する．各点滅パタ ーンの組み合わせを表 1 に示す. 点滅のパラメーターは点滅
周期・消灯時間・点滅方法の 3 つである. A は ONOFF寸る点滅 方法であり単純点滅と呼ぶ. B は徐々に光が暗くなり完全に光 が消えると徐々に明るくなる点滅方法でありフェードインフ ェードアウト点滅と呼ぶ. 点滅のパラメーターは点滅周期・ 消灯時間・点滅方法の 3 つである. 点滅方法のイメージ図を 図 1 に示す.

\section{2 実験概要}

被験者に点滅光を提示し, 点滅光時の脳波を測定，刺激の官 能評価を実施する.

以下に実験の概要を示す。

- 被験者：平均年齢 25.7 歳の健常者 26 名

・実験環境の明るさ : 201x（夜の街灯下の明るさを想定）

・点滅パターン数 : 12 種類 (表 1 にパターンを示す)

・視認距離 : $2 \mathrm{~m}$

・点滅を被験者にランダムに提示する.

\section{3 実験手順}

以下に実験手順を示す.

1）被験者に脳波計の電極を取り付ける.

2）被験者を実験室の照度 201ux の明るさに順応させる.

3）点滅の刺激と比較するために常灯を提示する. その後, 点 滅光を 30 秒間提示する.

4) 30 秒間の点滅光提示後, 被験者は, 常灯と比べた点滅光の 刺激の強弱, 不快感, 視認性, を $-3^{\sim}+3$ の 7 段階で評価する.

5）この点滅光 12 パターンの実験を晴眼と疑似弱視ゴーグル を装着して各 1 回行う. 